\title{
Perceptions of schooling, pedagogy and notation in the lives of visually-impaired musicians
}

\author{
David Baker and Lucy Green \\ Department of Culture, Communication and Media \\ UCL Institute of Education, London
}

\begin{abstract}
This article discusses findings on schooling, pedagogy and notation in the life-experiences of amateur and professional visually-impaired musicians; and the professional experiences of sighted music teachers who work with visually-impaired learners. The study formed part of a broader UK Arts and Humanities Research Council funded project, officially entitled "Visually-impaired musicians' lives: Trajectories of musical practice, participation and learning" (Grant ref. AH/K003291/1), but which came to be known as "Visually-Impaired Musicians' Lives" (VIML) (see http://vimusicians.ioe.ac.uk). The project was led at the UCL Institute of Education, London, UK and supported by the Royal Academy of Music, London, and Royal National Institute of Blind People (RNIB) UK, starting in 2013 and concluding in 2015. It sourced "insider" perspectives from 219 adult blind and partially-sighted musicians, and 6 sighted music teachers, through life history interviews, in tandem with an international questionnaire, which collected quantitative and qualitative data. Through articulating a range of "insider" voices, this paper examines some issues, as construed by respondents, around educational equality and inclusion in music for visually-impaired children and adults in relation to three main areas: the provision of mainstream schooling versus special schools; pedagogy, including the preparedness of teachers to respond to the needs of visually-impaired learners; and the educational role of notation, focussing particularly on Braille as well as other print media. The investigation found multifaceted perspectives on the merits of visually-impaired children being educated in either mainstream or special educational contexts. These related to matters such as access to specific learning opportunities, a lack of understanding of visually-impaired musicians' learning processes at times (including accessible technologies and score media) in mainstream contexts, and concerns about the knowledge of music educators in relation to visual impairment. Regarding pedagogy, there were challenges raised, but also helpful areas for sighted music educators to consider, such as differentiation by sight condition and approach, and the
\end{abstract}


varying roles of gesture, language, light, and touch. There was a diversity of musical participation in visually-impaired adult learners, along with some surprising barriers as well as opportunities linked to different genres and musical contexts, particularly in relation to various print media, and sight reading.

\section{INTRODUCTION}

This article reports findings on schooling, pedagogy and notation from a broader UK Arts and Humanities Research Council funded study. The project was officially entitled "Visuallyimpaired musicians' lives: Trajectories of musical practice, participation and learning" (Grant ref. AH/K003291/1), but came to be known as "Visually-Impaired Musicians' Lives" (VIML) (see http://vimusicians.ioe.ac.uk). It was led at the UCL Institute of Education, London, UK, starting in 2013 and concluding in 2015. It had two project partners, the Music Advisory Service of the Royal National Institute of Blind People (RNIB), UK and the Royal Academy of Music, London, UK; and was also guided by a panel of specialists in specific areas of visual impairment and music. ${ }^{1}$ In addition, advice on the medical aspects of eye health was provided by Vasuki Sivagnanavel, a consultant ophthalmic surgeon from the Royal Eye Unit, Kingston Hospital, London, UK. The project explored the musical practices, participation and learning experiences of visually-impaired people aged 18 years or over.

The primary research question was: "What are the experiences of visually-impaired musicians across the life course?" This was examined in relation to visually-impaired musicians':

\footnotetext{
${ }^{1}$ VIML contributed to the Royal Academy of Music's Open Academy outreach programme in 2014. We engaged music undergraduates with visually-impaired children at Edward Wilson Primary, London in forming a piece together through ear playing. This was facilitated with the kind assistance of Julian West (Head of Open Academy), Anthony Gritten (Head of Undergraduate Programmes) and Anette Dahyaraj, a teacher of the visually impaired at the school. Ahead of the musical encounters the undergraduates had with the disabled children, we primed them with findings included in this paper. The RNIB is the UK's largest charity concerned with visual impairment, which includes a Music Advisory Service (staffed by Sally Zimmermann and James Risdon). Our advisory committee comprised: Peter Bosher, an expert in accessible music technology; Jackie Clifton MBE, Research Fellow at the Royal College of Music, London, who is a severely sight-impaired musician; Kevin Kern, a visually-impaired composer and pianist from the US; Lord Colin Low of Dalston CBE, Vice President, RNIB; and Lydia Machell, who runs company, Prima Vista, concerned with technologies surrounding the production of Braille music.
} 
- learning practices, both as children and into adult life, including how, for example a blind musician prepares for a concert;

- involvement with different musical styles, instruments, practices and roles;

- sense of acceptance or marginalisation within professional, amateur and educational musical communities;

- opportunities and barriers perceived in relation to personal development and participation throughout the life-course.

Although the project was based in the UK and originally sought information on that national context, we were contacted by visually-impaired musicians from across the world (see later for details). Many of them were linked through shared experiences, and many networked via the internet. With the rapid growth of the project in this manner across 2013 to 2015, and building on our pilot work (Baker, 2014; and Baker, 2005a, b, c, 2006 on methodology) we report here a range of "insider viewpoints" specifically on schooling, pedagogy and print-based transmission media in music education. Other aspects of the project will be reported separately. ${ }^{2}$

\section{BACKGROUND, CONTEXT AND METHODS}

\section{What do we mean by a "visually-impaired musician"?}

VIML explored the lives of adult musicians (of 18 years or over) who, due to their visual acuity and/or visual fields, met the requirements for official registration by an ophthalmologist in the UK, even if they were from elsewhere in the world. ${ }^{3}$ Terminology in

\footnotetext{
${ }^{2}$ A co-authored book, Insights in Sound: Visually-Impaired Musicians' Lives and Learning (Baker \& Green) and a chapter "Visually-impaired musicians, community music and the 'disability arts' scene" (Baker \& Green, Oxford Handbook of Community Music, L. Higgins and B.-L. Bartleet, Eds.) are in preparation.

${ }^{3}$ Voluntary "registration" in the UK requires acquiring a Certificate of Visual Impairment (CVI) from an ophthalmologist and has benefits such as: practical support from social services departments; a reduced television licence fee; getting a disabled person's railcard; tax allowance; Disability Living Allowance (DLA); or free National Health Service (NHS) sight tests. Visual acuity and fields (the horizontal and vertical compass of sensations to the eye) are tested by the ophthalmologist. For more information and the benchmarks for registration, refer to "Registering your sight loss" on the RNIB website (and linked pages) at
} 
the field varies from organisation to organisation and worldwide, with many overlapping terms, including for example: "blind", "severely sight-impaired", "sight-impaired", "partially sighted", "functional vision" and "low vision". For the purposes of this article we use "visually impaired" as an umbrella term to denote people along a continuum from "sightimpaired", that is people with some degree of functional vision, partial sight, or low vision; to "severely sight-impaired", that is blind, having no or very little functional vision, or having a higher degree of impairment. Some people classed as severely sight-impaired may have no functional vision but with some residual light perception, or they may be entirely blind, with no light perception.

We consider a "musician" to be anyone who is involved in making music, whether as a singer or instrumentalist, conductor, DJ, composer or other music-maker; and anyone who self-identifies as being involved in teaching music in any capacity. Our interest was in people who participate in any musical genre, style, context or role, from adult beginners, to amateurs, semi-professionals and top professionals. There were two stipulations, however: this work did not directly investigate children's experiences, although we sought adults' accounts of their past learning and schooling as we will explain soon; and it was not about those with visual impairment combined with Profound and Multiple Learning Difficulties (PMLD). The latter area has been extensively researched by Ockelford (2000, 2007, 2008) and Ockelford et al. (2002, 2006) amongst others.

The World Health Organization's 2010 global estimates are 285 million visually impaired, with 39 million of these classed as "blind" and the rest as having "low vision" (WHO, 2012). Visual impairment comes from congenital, or "from birth" conditions and genetics (e.g. Leber's congenital amaurosis or ocular albinism), disease (e.g. diabetic retinopathy), the over-administration of oxygen to babies in incubators (e.g. retinopathy of prematurity), accidents and ageing. In the UK, the RNIB reports that there are almost 2 million people living with visual impairment, equating to one person in thirty, and they estimate that by 2050, the number will increase to nearly 4 million (from the RNIB website, 2014). In the US, there are over 6.6 million visually-impaired people according to the National Federation of the Blind. ${ }^{4}$ In Australia, there are an estimated 357,000 people who are "blind" or have "low vision" (from the Australian Network on Disability website, 2015). ${ }^{5}$

http://www.rnib.org.uk/livingwithsightloss/registeringsightloss/Pages/register_sight_loss.aspx (accessed 18 October 2013).

\footnotetext{
${ }^{4}$ Refer to https://nfb.org/blindness-statistics (accessed 9 September 2014).

${ }^{5}$ Refer to http://www.and.org.au/pages/disability-statistics.html (accessed 6 January 2015).
} 
The Canadian National Institute for the Blind (CNIB) reports that there are 479,083 citizens are with "vision loss" or "partial sight". 6 Approximately 125,000 New Zealanders have "vision loss", with around an additional 12,000 "blind". ${ }^{7}$ As distinct from people who are born with impaired vision, the commonest causes of sight-loss worldwide include cataracts and age-related macular degeneration. The global picture evidences a large amount of preventable sight problems too. ${ }^{8}$

Studying this arena inevitably raises important questions surrounding inclusion and equality. Here we consider the correspondence between visually-impaired musicians' understandings of the world around them, of education and learning, and equality that is stated in law through dictates such as the Special Educational Needs and Disability Act 2001 (SENDA, 2001) in the UK (also see DfES, 2001a, b); or the US Individuals with Disabilities Education Act 1997 (IDEA, 1997). The study also draws in the history and traditions of "blind musicianship", identities, and the varied manners in which different social and historical eras frame visually-impaired musicians. There are for example traditions of visually-impaired musicians and musicianship across the world, such as the Limba ethnic group in Sierra Leone (Ottenberg, 1996), minstrelsy in the Ukraine (Kononenko, 1998), the early jazz of the US Southern States (Batterson, 1998; Southall, 1999; Harrah, 2004; Rowden, 2009; Fuqua, 2011) and in Japan reaching back to feudal times, such as the Biwa Hōshi (lute) priests (De Ferranti, 2009; Lubet, 2011; Groemer, 2012). Prominent jazz and popular musicians in recent years too, such as Art Tatum, George Shearing, Ray Charles and

\footnotetext{
${ }^{6}$ Refer to http://www.cnib.ca/en/about/media/vision-loss/Pages/default.aspx (accessed 6 January 2015).

${ }^{7}$ Refer to http://blindfoundation.org.nz/learn/blindness/statistics-on-sight-loss (accessed 6 January 2015). One problem with collating or comparing figures on visual impairment worldwide is the array of overlapping terms used, with "sight loss" sometimes utilised to mean "partially sighted", even if sight has not been "lost", and "blind" used when there is residual light perception even if that vision is non-functional. In the UK, ophthalmologists have adopted the term "visually impaired" as an umbrella term for categories of "sight-impaired" (that is, visual acuity and/or fields deficient to the point of official registration) and "severely sight-impaired" (a higher degree of deficiency, including those who are "blind" and have no light perception). However, even these derivations are troublesome as "impairment" highlights a deficit model, which some dislike.

${ }^{8}$ Definitions of the sight conditions we mention throughout this paper can be found at the RNIB website at http://www.rnib.org.uk/eyehealth/eyeconditions/Pages/eye_conditions.aspx; Dr Michel Michaelides and the British Retinitis Pigmentosa (RP) Society at http://www.rpfightingblindness.org.uk/home.php; and Dr Andrew Blaikie and the Scottish Sensory Centre (SSC, Moray House School of Education, University of Edinburgh) at http://www.ssc.education.ed.ac.uk/resources/vi\&multi/eyeconds/list.html. Information and downloadable booklets on a range of conditions can also be found on the Royal College of Ophthalmologists (UK) website at http://www.rcophth.ac.uk/page.asp?section=365\&sectionTitle=Information+Booklets (all accessed 28 September 2014).
} 
Stevie Wonder have undoubtedly amplified society's interest in the connection between visual impairment and music, in addition to quirky characters such as Moondog "The Viking of Sixth Avenue". ${ }^{9}$ Whilst some such names can reasonably be described as world-famous, there are large numbers of other visually-impaired professional musicians who are recognised experts in their fields, such as the concert pianist Nobuyki Tsujii, the classical singer Andrea Bocelli, the lute and theorbo player Matthew Wadsworth, the country singer Hayley Oliver, the rock musician Joey Stuckey, and the classical composer Michael Stimpson, to name only a few; and there are countless other amateur, aspiring professional or semi-professional visually-impaired musicians in countries throughout the world.

There is also a thriving "disability arts scene" of "blind ensembles" worldwide, which includes for example the Inner Vision Orchestra, a UK world music ensemble; the British Para-orchestra, which played at the London 2012 Paralympics with the pop band Coldplay and has both visually-impaired members and those with other disabilities; the Al Nour Wal Amal ("Light and hope") Chamber Orchestra in Egypt, which is comprised entirely of visually-impaired women (Lubet, 2011; Lababidi \& El-Arabi, 2002); the Korean Traditional Music Orchestra of the Blind; the Argentinian National Symphony Blind Band "Maestro Pascual Grisolia"; and, in Chennai, India, the St. Louis Blind Orchestra, which performs music from Tamil cinema (informally known as "Kollywood"). Surrounding all this, too, is "social lore" such as, in the past, higher religious wisdom being attributed to itinerant minstrels or, in current society, the sighted person's assumption, correct or otherwise, that "in the absence of one sense another is augmented". Indeed, research and scholarly writing has explored notions of heightened musical cognitive and auditory capacities in visually-impaired people (e.g. Welch, 1988; Hamilton, Pascual-Leone \& Schlaug, 2004; Melcher \& Zampini, 2011; Dimatati et al., 2012).

Music can have an important part to play in the formal education of visually-impaired children and adults across their lives, as well as within their extra-curricular, communitybased, informal, and other activities. Whilst musical participation for children and young people has long been considered highly worthwhile, the UK's cross-council New Dynamics of Ageing research project and "Music for life" have also shown how musical participation is

\footnotetext{
${ }^{9}$ The iconic visually-impaired American poet and musician, "Moondog" (Louis Thomas Hardin, 1916-1999), could be found from the 1940s to 70s in New York, where he composed, performed and sold his music on a street corner dressed in a horned Viking helmet. He was linked with people such as the jazz musicians Benny Goodman (1909-1986) and Charlie Parker (1920-1955), English pop musician Elvis Costello (b. 1954), US singer-songwriter Janis Joplin (1943-1970) and the French designer Philippe Starck (b. 1949).
} 
important for older people's wellbeing, social lives and self-image (Hallam et al., 2010, 2011). ${ }^{10}$ Music education is not merely something that occurs within school walls but can be a lifelong process (see Myers, 1995, 2008; Roulston, 2010). Sight-loss is more likely late in life, and this area is crucial, both for adult musicians who lose their sight and need to adapt their musical practices; and for those for whom other new pastimes may be harder to access.

In sum, we are interested in visually-impaired music-makers and music teachers from beginners to professionals, in any musical style, role or context. Aside from literature mentioned above, there is but a small quantity of literature specifically on music pedagogy (e.g. MacLeod, 1987; Zimmerman, 1997; Clark \& Murphy, 1998). In particular, there is little research cutting a broad swathe across visually-impaired musical insiders' perspectives on lived experience in schooling, pedagogical practice, or their approaches to reading music. It is especially in these areas that we hope to contribute in this article.

\section{Setting up the project and contacting respondents}

We developed a website (see http://vimusicians.ioe.ac.uk) in order to foster awareness of the project, as well as to help disseminate findings and events. Many sighted people may not realise that even blind or severely sight-impaired people can access electronic media such as web pages, software applications, e-mail and other digital file formats (e.g. for word processing) with "screen reader" software, which generates audio (synthetic voice) from elements and text normally viewed by users. The navigation of, say, web pages is by keystrokes. Sometimes text-to-speech software is also used in conjunction with a hardware device, such as a refreshable Braille display. James Risdon, a member of our team who is severely sight-impaired, tested our website and other electronic materials using two popular screen readers and his tactile display (e.g. JAWS [Job Access With Speech] and NVDA [Non-Visual Desktop Access]). We also implemented W3C web standards on accessibility and sought further advice from the RNIB. "Sight-impaired" (or low vision) computer users sometimes use dedicated magnification software (e.g. iZoom, MAGic, SuperNova, ZoomText) alongside the zooming capabilities of web browsers; simply using a large font

\footnotetext{
10 "Music for life" was a component research project of New Dynamics of Ageing (NDA). NDA was an eight-year multidisciplinary initiative to improve quality of life for older people. NDA was funded in the United Kingdom by the Economic and Social Research Council (ESRC), BBSRC (Biotechnology and Biological Sciences Research Council), Arts and Humanities Research Council (AHRC), EPSRC (Engineering and Physical Sciences Research Council) and the MRC (Medical Research Council). The "Music for life" project collaborators were Guildhall School of Music and Drama (GSMD), The Sage Gateshead and Westminster Adult Education Service (WAES).
} 
can be a problem for people with restricted visual fields (as in "tunnel vision"). We included a re-sizeable text computer script on our homepage, although, no doubt, many sight-impaired people accessed the text with their own accessibility software.

We had considerable support from a range of organisations concerned with visual impairment and music. Initially, the RNIB facilitated contact with some of their clients, and thereafter, "word of mouth" took over. Some respondents put us in touch with colleagues or friends, sometimes asking them to contact us; and quite quickly we were independently emailed by people who had come across us by one means or another. Many of them helped by putting notices on their websites or Facebook pages, linked to ours, or they sent out information in newsletters and e-bulletins. Our supporters grew to include: the Blind and Low Vision Education Network (BLENNZ, New Zealand); the European Blind Union; the Music Education Network for the Visually Impaired (MENVI, USA); Music Mark (the UK Association for Music Education); the National Federation of the Blind (USA); RNIB (UK); the Royal London Society for Blind People (UK); Thomas Pocklington Trust (UK); Vision Australia; the World Blind Union; and many more. In tandem with this "formal" dissemination of our activities, we soon found ourselves at the heart of national and global networks of musicians, who put friends and colleagues in touch with us.

\section{Our sample and methods}

Our participants came from and lived in a range of countries, as we describe later in this section. Altogether we collected data from 225 people, ${ }^{11}$ broken down as follows: interviews with 48 visually-impaired musicians/music teachers of whom 20 also completed our questionnaire; and interviews with an additional 6 sighted music teachers who work with visually-impaired learners (54 interviews in total). We also collected questionnaire data from an additional 171 visually-impaired respondents (so 191 questionnaire responses overall). Of the 219 visually-impaired respondents, 78 reported that they had their current level of vision at birth or before the age of five years, i.e. at or near the onset of compulsory UK schooling

\footnotetext{
${ }^{11}$ The eye conditions of our respondents included cataracts, diabetic retinopathy, glaucoma, high myopia, Leber's congenital amaurosis, macular degeneration, microphthalmia, nystagmus, ocular albinism, retinal detachments, retinitis pigmentosa, retinoblastomas, retinopathy of prematurity, Stargardt's disease, uveitis, and some resulting from accidents. Respondents also mentioned secondary eye-health problems such as astigmatism, cataracts, glaucoma, nystagmus and retinal detachments.
} 
(61 severely sight-impaired and 17 sight-impaired respondents). Many provided vague remarks such as "Sight loss was observed at the age of five but the loss itself was exceedingly gradual" or "Vision has been degenerating since birth"; others were in a position to be more specific, such as "Sudden after a stroke". Others indicated a plethora of ages at which they lost vision. It was clear that many could not, with the complexities of their particular experiences combined with the fallibility of memory, pinpoint when their sight became an issue at all. Educational perspectives are likely connected with specific, individual anamneses of which there are a huge array (alongside many other life factors), rather than serving as views that could be cross-tabulated easily with variables such as "congenital" and "adventitious blindness". We do acknowledge, therefore, that the experience of a child who is blind from birth or in the first months is different to someone who loses his or her sight later on. We do welcome further research that explores how particular conditions or points of official registration affect perspectives on schooling and, indeed, music education more broadly. Amongst the interview participants the spread was biased towards people living in the UK, with 42 respondents, and 12 from other countries. The reasons for this were partly pragmatic, and partly to do with the fact that the project was UK-funded. The questionnaire respondents came from a much wider range of countries, although with a bias towards the larger English-speaking countries, including the UK, USA, Canada, Australia and to some extent New Zealand. All our respondents spoke English, either as a first language or an alternative language. Given our sample size and its uneven spread across different countries, it is of course not possible to generalise across these contexts. But it is reasonable to make at least some tentative generalisations and, where it seems feasible, we do so in the main body of the article.

\section{The interview sample}

Between July 2013 and March 2014, the first author conducted 54 life history interviews, lasting from one to two-and-a-half hours, with musicians and/or music teachers who were visually impaired. Forty-two of the interviewees were from the UK, 6 from the USA, and 2 from Australia, with individuals from Colombia, Indonesia, Malaysia and New Zealand. The mean age of the 51 declared was 44.04 years (standard deviation, SD =15.28), with the youngest interviewee being 18, and the oldest 73 years of age. Thirty-five of the interviewees were "severely sight-impaired", and 13 were "sight-impaired". They played a range of 
instruments, often in combinations, with 28 keyboard players, 22 singers, ten percussionists (including two who played Indian percussion) and varying numbers of others playing woodwind, string, and brass instruments. There were 17 composers, with seven who were "notation-based" (i.e. utilizing Braille, large-print or modified stave notation, etc.), 12 who produced or recorded electronic music, and a DJ working with Bhangra music. ${ }^{12}$ Thus, the musicians were involved in classical, jazz, pop, rock and traditional or "world" musics.

A further six interviews were conducted with sighted music teachers who specialise in working with visually-impaired students. Two of them worked in prominent UK special schools for the visually impaired - the Royal Blind School, Edinburgh (Louisa Maddison) and Linden Lodge School, London (Susan Wynn). One worked with visually-impaired adults at the Royal National College for the Blind in Hereford (Cara Tivey). Imogen Triner, a professional oboist, worked with visually-impaired and sighted instrumental students in private practice. Angela Pino Hoyos of Pontificia Universidad, Javeriana, Colombia was involved with visually-impaired undergraduates and school-age music students. Mark Miller, a jazz piano teacher from Chicago, teaches visually-impaired students across the world - in San Francisco and Washington (USA), Colchester (England), Dubai (United Arab Emirates), Hong Kong and Oslo (Norway) - via Skype, e-mail, podcasts, telephone and electronic files in a bid to challenge problems of "independent mobility" and thus increase access to instrumental tuition.

As well as these sighted teachers of visually-impaired students, 12 (25.00\%) of the visually-impaired interviewee sample identified themselves as music teachers. One of them was Chi Kim, developer and Director of the "Music technology lab for the visually impaired", a programme of accessible music technology at Berklee College of Music in Boston, USA. The others worked in a range of contexts, mostly in private practice. As well as discussing pedagogy with the teachers, we asked all the visually-impaired musicians we interviewed (and the questionnaire respondents) for their views about apt pedagogical principles for their disability, as well as about schooling, derived from their life-experiences as learners, school pupils and students.

\section{The interview method and content}

\footnotetext{
12 "Bhangra" refers to an upbeat popular music style, which became prevalent in Britain in the 1980s as a cultural product of young people of the Punjabi diaspora. It typically features the dhol (an Indian percussion instrument).
} 
We used life history method, which emerged between the World Wars in the Chicago School of Sociology. Since then, biographical research of various types (e.g. Bertaux, 1981; Bertaux \& Kohli, 1984; Armstrong, 1987; Sparkes, 1994) has become established in sociology to explore a range of social groups, often focussing on the disenfranchised, "deviant" or otherwise excluded social group (Thomas \& Znaniecki, 1919; Shaw, 1930; Lewis, 1961; Sikes, 1985; Dollase, 1992; Casey, 1993; Huberman, 1993; Huberman \& Marti, 1993; Munro, 1998; Barrett \& Stauffer, 2009, 2012). We felt that the combination of life history interviews with a questionnaire, see below, would produce a rich dataset and also allow us to reach out widely. The expansiveness and collaborative nature of life history interviews is advantageous as it permits respondents to introduce matters that they consider important; and themes can be introduced by respondents rather than being solely driven by pre-conceived ideas, as in a survey instrument derived from literature and/or researchers' assumptions. We believed that research based largely on sighted investigators' preconceived ideas would have been less beneficial. 'Voice' (Elbaz, 1990) and empowerment are integral to life-history work. One downside to life histories, however, is that each account produces such voluminous data that, given the project staffing, it would have been impossible to collect, transcribe and analyse more than the current quantity of interview matter. The questionnaire afforded the potential to collect data from a much larger sample of visually-impaired musicians. Most of the questions required tick-box answers, but there were also opportunities for respondents to write in prose, explaining their reasons for answers, introducing ideas or raising issues that they felt the questionnaire did not cover. Those responses were also included in our analysis.

An information sheet was given to the interviewees in Word format (mainly electronically which, as explained above, can be read by visually-impaired people using assistive technologies). There was also the offer of a copy in Braille or another preferred format, which none required. The document detailed our aims, procedures and ethical arrangements. ${ }^{13}$ It was made clear that participation was voluntary, that we would provide further information if desired, and that participants could withdraw at any point without giving a reason; none withdrew. Although we offered to visit respondents' homes, most of

\footnotetext{
${ }^{13}$ We used the British Educational Research Association's ethical guidelines which can be downloaded from http://www.bera.ac.uk/ and http://www.bps.org.uk/ respectively; in combination with the Institute of Education, University of London's ethical procedures which can be found at http://www.ioe.ac.uk/about/policiesProcedures/41899.html (accessed 28 September 2014).
} 
the interviews took place via Skype (usually without use of the webcam), which was the favoured method of the interviewees. We agreed with the respondents that arranging an interview comprised "informed consent" (Glesne \& Peshkin, 1992; Cohen, Manion \& Morrison, 2000; Silverman, 2000; Gregory, 2003; Ryen, 2004). Our discussions were audio recorded and transcribed.

Questions relevant to this article included:

- Can you tell me about your past experiences and participation in music?

- To what extent do you believe that the opportunities to learn music for visuallyimpaired and sighted people are equal or unequal?

- What was the music teaching like at school and/or in instrumental lessons?

We asked specialist teachers questions including:

- Have you needed to change your typical teaching practices to work with your visually-impaired student or students, and if so in what ways?

- What have you learned about teaching music to visually-impaired people that would benefit other teachers?

The life-history texts were returned to interviewees, who evaluated their "internal consistency" (Atkinson, 1998, 2001). Aside from assessing fidelity, the completed transcript was an opportunity for interviewees to flag sensitive remarks not to be published. Except where interviewees are happy to be named, we use pseudonyms and have removed other "identifiers" from the transcripts. Nevertheless, owing to respondents belonging to a small and well-networked disability groups worldwide, complete anonymity could not always be assured, and interviewees were aware of this (e.g. colleagues spotting them from idiosyncrasies of speech or from their profiles).

\section{The questionnaire sample}

We received 191 questionnaire respondents, of whom $20(10.47 \%)$ also contributed to the interviews; so there were 34 interviewees who did not contribute to the questionnaire (28 
visually-impaired participants and 6 who were sighted). There were 78 (40.84\%) from the UK; 48 (25.13\%) from the USA; 23 (12.04\%) from Australia; 13 (6.81\%) from Colombia; 5 (2.62\%) from New Zealand; 4 (2.09\%) from Canada; 2 (1.05\%) from Austria, 2 from Italy and 2 from Kenya; and single respondents from Chile, Croatia, Egypt, Estonia, Fiji, Ghana, India, Indonesia, Italy, Japan, Malaysia, the Philippines, the Republic of Ireland and Russia. One hundred and forty-six (79.44\%) classed themselves as "severely sight-impaired", the rest "sight-impaired". There was a good distribution of ages, with: 40 of 18-24 years; 50 of 2534 years; 29 of 35-44 years; 27 of 45-54 years; 33 of 55-64 years; and 12 of 65-74 years. There appeared to be no particular bias towards older people, which was rather unexpected, bearing in mind increasing demographics of sight loss in the elderly due to conditions like age-related macular degeneration. All the respondents were musicians, and several respondents identified themselves as music teachers too: instrumental teachers (40, 20.94\%), community music leaders or animateurs $(22,11.52 \%)$, class music teachers $(21,10.99 \%)$, and singing teachers $(19,9.95 \%)$. A range of instruments was played and/or taught, associated with various genres, including classical, folk, gospel, hip hop, Latin, popular, traditional and other "world" musics. The instruments included banjo, ukulele, mandolin, Indian harp, Indian sitar, Iranian tar (a plucked string instrument), viola da gamba, violin, cello, penny whistle, recorder, Western concert flute, Japanese shakuhachi flute, clarinet, saxophone, didgeridoo, trombone, guitar (acoustic and electric), harmonica, harmonium, accordion, keyboards (electronic, harpsichord, "church" organ and piano), Western (orchestral and kit) percussion, Indian dhol, and African percussion.

\section{The questionnaire method and content}

We created the questionnaire (available at the project website, see above) using the online facility Survey Monkey ${ }^{14}$ for both contextualising quantitative data (from multiple option, closed "yes/no" items and five-point rating scales); and qualitative elaborations on those responses. We adopted this approach so as not to "...leave respondents with the impression that their personal opinions or experiences... [had] to fit into a straightjacket of prescribed answers" (Gillham, 2007, p. 34). The questionnaire was anonymous and sourced information

\footnotetext{
${ }^{14}$ Survey Monkey is a cloud-based US online questionnaire company founded in 1999 by Ryan Finlay. It can be found at http://www.surveymonkey.com (accessed 22 August 2013). RNIB had used SurveyMonkey for staff questionnaires so we had faith in its compatibility with accessibility software.
} 
on demographics of musical participation (e.g. contexts, genres, roles) alongside attitudes to visual impairment and music, including schooling and pedagogy. A hyperlink was placed on our project website and was also sent to our contacts by e-mail. The questionnaire could also be completed with us by telephone or Skype, too, although only a few respondents took us up on that offer. For the quantitative data, SPSS software was used to explore frequencies, means and distributions and to cross-tabulate variables; and the qualitative responses were analysed in the same way as the interview data.

\section{FINDINGS}

Although our sample is too small to warrant global generalisations, we feel it is worth noting that across our interview and questionnaire respondents, the diversity in musical participation - including instruments played, musical styles and genres, and musical practices - surprised us. We had started with a preconception that, without functional vision, people would be more inclined towards musical arenas with an emphasis on ear playing, improvisation and oral traditions, rather than those heavily based in notation or involving visual responses such as following a conductor. That this seems not to have been the case, at least across this particular sample, is partly due, of course, to the kinds of educational opportunities that were offered to the participants as young visually-impaired learners whilst they were at school; and also the previous musical experiences of those experiencing sight-loss later in life, who may have already developed skills in a range of musical arenas and wished to carry them on.

\section{Schooling}

McCall (1997) traces the development of educational services for children and young people with a visual impairment from the establishment of special schools for the blind as "the norm for blind children" (p. 6) noting about the UK "Anxieties...began to surface about the narrowness of the educational choice available to parents..." (p. 10) in the 1960s and 70s; there were consequent situations whereby children from residential schools, supported by their teachers, were sent to mainstream schools for lessons. Results suggested “...with the right level of support, some children who were educationally blind could succeed academically in mainstream schools" (ibid.) yet, he explains, expertise in supporting those 
children was to be found in special schools. McCall notes an acceleration of growth in local authority advisory services for children with visual impairments in the 1980s, and that children with partial sight were commonly educated in the mainstream; thus the surviving special schools had to embrace a much wider range of ability. Worldwide, schools for the visually impaired continue. Provision now includes: mainstream schools supported by peripatetic specialists; special schools for visually-impaired children; other special schools for those with severe learning or physical difficulties; and mainstream and specialist colleges of further education (e.g. see Kirkwood \& McCall, 1997). In the UK, USA, Canada, Australia and to some extent New Zealand, the tendency of policy-makers has been to place visuallyimpaired children who do not have developmental delay or learning difficulties into mainstream education, along with providing specialist support services and requiring schools to make "reasonable adjustments". ${ }^{15}$ Surveys published by the RNIB suggest that in England, Scotland and Wales, there are over 25,000 children and young people with visual impairments in compulsory education, with 60-70\% in mainstream schools (Morris \& Smith, 2008; RNIB, 2013a; Keil, 2012a, b). Mainstreaming is also evident in the US with the Individuals with Disabilities Education Act (IDEA, 1997), which ensures that, where viable, visually-impaired children are placed in educational environments with a general population of students. The nature of schooling for the visually impaired has certainly changed across the world away from predominantly residential schools yet with increased choice and special education surviving albeit in different forms to the past, we found a live debate within this community, with strong sometimes contrasting viewpoints, on which is the best context for schooling: mainstream or special education?

\section{Protagonists for special schooling}

The first author visited the Royal Blind School, Edinburgh in September 2013 where teachers in the staffroom stressed the profoundly specialist nature of their work, including music tuition. Overall, the sentiment was that mainstream schooling was "not in the children's best interests", it was "isolating" and it "hindered the development of life skills". Several interviewees remarked on this too (as did this congenitally-blind respondent):

\footnotetext{
${ }^{15}$ See e.g. the IDEA (1997) on the US context, Atkin et al. (2003) on Canadian national standards and Ruddock and Bishop (2006) on Australia.
} 
...people who went to sighted schools...were, quite often, left out of things. (Sarah, oboist, severely sight-impaired; interview, UK)

Sometimes the problems reported were more to do with "fitting in" with the mainstream, and this could affect music-making in a range of ways. For instance, one sight-impaired respondent in her 20s, whose sight declined rapidly during primary education, recollected appearing "different", not only because of being visually impaired but partly due to sitting alongside a teaching assistant in class, and finding herself bullied by other children. As a result she disengaged from musical activities (Amelia, electric bass player and rock musician, sight-impaired; interview, UK).

The demands of the general curriculum in mainstream schools may also be a barrier to musical participation. As another interviewee who was congenitally blind remarked:

There might also be the very simple fact that, as a visually-impaired kid now in a mainstream school, you haven't got time to participate in a lunchtime orchestra because you're busy off learning Braille or your independent living skills or mobility, using a white cane, or catching up on science because you need a bit more time to do stuff. I think the curriculum has made it very much more difficult to find time to do all these extra-curricular things. (Jonathan, woodwind player, severely sight-impaired; interview, UK)

Others, such as one interviewee from the US, suggested there were limited resources for the visually impaired in mainstream schools in her rural area, and limited access to specialist services, including music tuition. For these reasons she attended the Georgia Academy for the Blind in the 90s (Emily, singer, severely sight-impaired; interview, USA).

\section{Upsides to mainstream schooling}

In favour of mainstream schools, several respondents, such as in this example of someone with declining sight during childhood, commented that "by the law of numbers", there would be more children involved in music (formally and informally) and, therefore, more musical opportunities (e.g. Richard, pianist, accordionist, singer and recording engineer, severely sight-impaired; interview, Australia). From the opposite vantage-point, but in accordance 
with this view, another congenitally-blind respondent mentioned that, because of attending a special school for the visually impaired, it had been difficult to engage with musical activities in the wider community:

...if you are in a mainstream school near where you live, you have the choice of joining in local musical activities. ...At the time, there was no option for that, because [my special school] was a boarding school, so whatever I did was with the other children in the school. I was only home during the holidays. I lived in a small village and there wasn't anything going on there. ...I would think it would be a very good thing to be involved in local activities. (Paul, flautist, guitarist, keyboardist and music technologist, severely sight-impaired; interview, UK)

Particularly amongst the younger interviewees from the UK and US, the benefits of attending mainstream schooling were felt to include the opportunities for social interaction and adjusting to participation in sighted society.

Our questionnaire had a number of rating scale statements with five points from "Strongly disagree" (or numerically 1) through "Neither disagree nor agree" (3) to "Strongly agree" (or 5) (refer to Table 1, below). One of these was "Visually-impaired people and sighted people have equal opportunities in relation to music education" (140 responses to the question). The mean score for this was 2.42 ( $\mathrm{SD}=1.11$ ). Another statement was "Visuallyimpaired people have better musical learning experiences in mainstream schools than special schools" (127 responses), which generated a mean of 2.76 (1.08). On both statements, then, an average response has been "disagreement with the statement" (i.e. below the neutral midpoint of the scale). But the raw scores are dispersed, which mirrors the mixed, cacophonous nature of the discourses that emerge surrounding schooling, school type and music.

Table 1. Questionnaire responses to five-point rating scales ("Strongly disagree" = 1, "Neither disagree nor agree" $=3$, "Strongly agree" $=5$ ).

\begin{tabular}{ll}
\hline Questionnaire statement & Mean \\
(standard deviation, SD) & [no. of responses]
\end{tabular}

Visually-impaired people and sighted people have equal opportunities 2.42 (1.11) [140] in relation to music education

Visually-impaired people have better musical learning experiences in $\quad 2.76$ (1.08) [127] mainstream schools than special schools 


\section{Music curriculum and pedagogy}

In terms of curriculum and pedagogy, "equality" with the sighted cannot equate to "sameness" in content and delivery; (on avoiding a "deficit model" of disability, see Webster \& Roe, 1998; Silvers, Wasserman \& Mahowald, 1998). "Differentiation" in order to cater for differing needs and abilities of different students, is normal whether or not teachers are working with students with special educational needs. But the effective teaching of music to visually-impaired students implies some particular specialisms such as knowledge of sight conditions, learning processes related to score formats, accessibility technologies and their compatibility with music software. Other important themes that surfaced included the need for teachers to embrace high levels of "flexibility" as well as differentiation; the connotations of "light" in learning and in the learning space; how aspects of "gesture" are configured; the places of "visual metaphor and language use" in pedagogy; and the relevance and use of "tactile" approaches.

Our questionnaire asked for a response to the statement: "Sighted music teachers are generally aware of the needs of VI learners" (137 responses). This produced a mean of 2.05 (0.99), or an average response of "Disagree" (which did not surprise us). Interviewees made comments like "a lot of staff (in the mainstream school) didn't know how to support me" (Simon, drummer and music teacher, sight-impaired; interview, UK) or "I don't think they had a particular strategy to help; it was just the standard strategy the music teacher would do" (Arjan, Indian percussionist and DJ, sight-impaired; interview, UK). Some of the respondents suggested that they were left to articulate specific needs, rather than the teacher being prepared. This is daunting for a young child wanting to fit into classes, and often requires what could be referred to as substantial confidence or even extroversion:

If they were writing something on the board, you know, I would say "Can you describe what you are doing? Can you make that more verbal?” ...I just toughed it out 
with everybody else; I didn't go to a special school for the blind. ...It honestly was left up to me to be resourceful. (Anthony, rock musician and music producer, severely sight-impaired; interview, USA)

Amanda recollected that it was difficult to get the level of confidence she required right, since her behaviour was liable to be read as arrogance and poor attitude by adults, including teachers, and thus cause problems.

Yes, you need 100 times the confidence of your sighted peers [as a school-age pupil]. The difficulty for me actually was trying not to appear arrogant with it, if you see what I mean, because you can sometimes overstep the mark. (Amanda, singer, pianist, flautist, accordionist and music workshop presenter, severely sight-impaired; interview, UK)

\section{Flexibility and differentiation}

For the educators amongst the interview sample, non-uniformity in visual perception (or its absence) meant that careful assessment of students' needs, particularly resulting from their specific eye condition, and also a high level of differentiation in classes became paramount, along with flexibility. Louisa Maddison, Head of Music at the Royal Blind School in Edinburgh explained the need for differentiation within her classes:

I think knowing about the different visual impairments straight away would have been very useful [when I started teaching]. There are so many different types and, with some pupils, if you present an instrument below their chin, they can't see it. If you hold it to the side, they can. If you have five partially-sighted people in the class, if you treat them all similarly, you could be doing a big disservice to a lot of them, so you need to know what their field of vision is before you start working with them. ...With partially-sighted pupils or adults, there are so many eye conditions...You have to differentiate everything...Every pupil [I teach] is different, and they are accessing things differently, or working in different ways. You might have two pupils using Braille, one using large print, one using audio, [or] some pupils who can access large print but it takes them a long time to read. They [may] prefer to have things on a 
$\mathrm{CD}$ and listen to it, [to] memorize it... (Louisa Maddison, Head of Music, Royal Blind School, Edinburgh, Scotland, sighted; interview, UK)

\section{Light}

For students with some light perception, (even non-functional vision in severely sightimpaired pupils), ambient and artificial light are considerations. Light has the potential to impinge on reading lustrous or translucent paper scores (or glossy whiteboards), due to glare for pupils suffering from, say, photophobia (e.g. due to uveitis or ocular albinism); and it could affect the best orientation of students in rooms. Of course, artificial light can be controlled to some extent (such as with dimmer switches, lamp shades, by means of bulb types and their Watt rating, or by simply repositioning lights), but it may be harder to take charge of ambient light (such as high-energy sun-rays streaming through a window), at least without effective curtains or blinds. The RNIB gives the following advice:

Seeing the teacher, who may be anywhere in the room, seeing other children in your performing group, seeing the instrument you are playing and being aware of the reactions of those just listening are all part of music making in school. That is all before the winter sun streams in through half of the room... For those with some useful vision, finding the best position for the most important of these is important. Look out for odd body posture and tension that might be avoided by, say, sitting in the best lit part of the room or close to the teacher's workstation. Have a music stand with a hard back... (2013b, p. 6).

As expressed by Louisa Maddison:

...some of them are bothered by the lights so they have to wear darkened glasses, so you are dealing with a classroom where everyone has different needs. Some might need a lot of light because they can see better like that, so it is about weighing things up and trying to get everybody to perform at their best level. ... if the pupils' vision is affected by external light, would the sun coming in from the window bother them or would the lights bother them? Or, do you need all the lights on full, for them to see to 
their best ability. (Louisa Maddison, Head of Music, Royal Blind School, Edinburgh, Scotland, sighted; interview, UK)

\section{Gesture}

It is worth making a distinction between a broad definition of "musical gesture" encompassing music's sonorous aspects (see Gritten \& King, 2006, p. xx), and "physical gesture in music", connoting bodily movement or posture to produce sound, to guide others in a performance, to convey expression, or, during a music lesson, to elicit desired behaviour or rapport. Such aspects of general and musical communication as well as behaviour management in many school situations, ensembles or musical learning groups, are predominantly visual. ${ }^{16}$ Sighted learners can scan the room with their eyes to know who is around them, or to discover if their behaviour is acceptable to their peers; but this is not so available for those with a visual impairment. The gestural aspects of music teaching can include: pointing, nodding; facial expression, e.g. smiling to convey to a student he or she has done well, or conversely a frown of displeasure. This includes demonstrating touch or a wrist action at an instrument. Gesture is deeply and implicitly part of all teaching, rehearsing and performing music, and is explicitly integral to music education traditions such as Kodály, Curwen and Dalcroze. Our interviewees suggested that self-awareness from sighted teachers in this area was important. Sometimes, all that is required is a teacher realising the importance of saying: "that is correct, good" rather than giving a nod of approval; or "That is out of tune" rather than raising their eyebrows.

The "stage craft" and the "visual constituents" of being a musician needed to be a conscious, verbalised undertaking by teachers as well. Uncertainties about gesture or posture (or just wider presentation), for the visually-impaired musician or learner could affect his or her confidence. One respondent worried, for instance, that perhaps he was not standing the right way during performances or wearing clothes that did not match other ensemble members (Paul, flautist, guitarist, keyboardist and music technologist, severely sightimpaired; interview, UK).

\footnotetext{
${ }^{16}$ Argyle (1988) has divided bodily communication into aspects of: tone of voice, touch, verbal communication, orientation, proximity, facial expression, gaze, and posture. These apply to musical learning, some of which we might class as gestural; their relative weight when working with visuallyimpaired learners depends upon their particular sight condition and visual acuity.
} 
Visual metaphor and language use

How often, as musicians, we speak of things like "a bright tone", a "dark or focussed timbre", a "deep texture" or "an angular melody"; or we draw parallels with areas of visual experience; and of course, Romanticism ushered in artistic products to light up our imagination with images of nature, particularly in programme music. Several of our interviewees noted that, with the youngest learners, those with congenital conditions resulting in no functional light perception at birth, concepts could be poorly understood. It is easier to relate the lumbering weight and movement of the elephant in Carnival of the Animals (SaintSaëns) when you have seen one move. Or there could be other "abstracts" that teachers need to be careful about. The interdependence between vision and interacting in the world means that "...visual loss or impairment can have a significant impact on the developing child" (Miller \& Ockelford, 2005, p. 11). There is even evidence of language delay in the early lives of visually-impaired children, particularly in terms of pragmatic language use, which is redressed by school age (Tadić, Pring \& Dale, 2010); yet we can only wonder at exactly how language development affects musical learning in this group. As a sighted teacher of visuallyimpaired children and young people remarked:

...there are so many things that we say in everyday language that we have it as a given that sighted people will understand. But you've got to make sure that it's not an abstract for a visually-impaired person, because you might ask people to do something very simple and they might not understand. (Fiona, teacher at a special school for the visually impaired, sighted; interview, UK)

\section{The tactile}

Another consideration for teaching that the interviewees mentioned was the importance of "the tactile" in learning music. At the Royal Blind School, Edinburgh, the first author sat alongside a blind primary-age student playing the drum kit in a class ensemble, who gently felt his way around the cymbals and snare with his hands to locate the kit and position himself. The author and student held the sticks together to work together on the rhythm. 
Elsewhere, a singing teacher (anon.) spoke about having a student's fingers on her lips, to show them a $U$ or $E$ shape, which in light of Child Protection and educational work in "sighted" contexts may seem "uncomfortable" to many teachers, and might even be considered inappropriate in some contexts. Undoubtedly, the boundaries should be mutually agreed with parents, schools, professional organisations and students. David Pinto mentions the importance of a tactile approach in the acquisition of instrumental technique. He writes:

Since [visually-impaired students] can't see others playing their instruments, they can't "model" their technique on any visual example. Therefore, a teacher must often physically show the musician correct finger, hand, arm, and torso positions and use of the corresponding muscles. Although some blind individuals may develop a good technique instinctively, a good sighted teacher can always help them in that regard. ${ }^{17}$

We also came across severely sight-impaired music teachers who underscored the importance of learning stave notation through tactile means as a child (as explained in the quote below). This, they remarked, had allowed them to become music educators of sighted children. Submersion across the life-course only in highly specialised mediums and ways of learning music may affect visually-impaired people's ability to pursue teaching if they wish.

...the teacher [in the primary school] did not know how to teach Braille music. She had the lines drawn on the Braille paper and stuck note-heads that she cut out and that's how I learned what the print music looks like. ...I think it was good that I learned what my sighted peers learned in terms of print music. I like the fact that the majority of people around me can see. It's good that I can understand what they can see and how I can present things in a way that they can appreciate and learn or understand, so I believe that has helped me a lot now that I have sighted [piano] students. It makes sense for them to read print notation and not by another method. (Audrey, pianist and piano teacher, severely sight-impaired; interview, Malaysia)

\footnotetext{
17 "Devoted to Teaching Music to the Blind: Interview with David Pinto, Executive Director of Academy of Music for the Blind" from The Epoch Times (online), 21 December 2009 at http://www.theepochtimes.com/n2/arts-entertainment/blind-music-instruction-academy-david-pinto26744.html (accessed on 20 January 2014). The Academy was supported by Ray Charles (1930 2004). It is in Los Angeles, California, USA and provides music tuition to children of 4 to 18 years of age. See http://www.ouramb.org/
} 
Fig. 1: Some considerations for pedagogy.

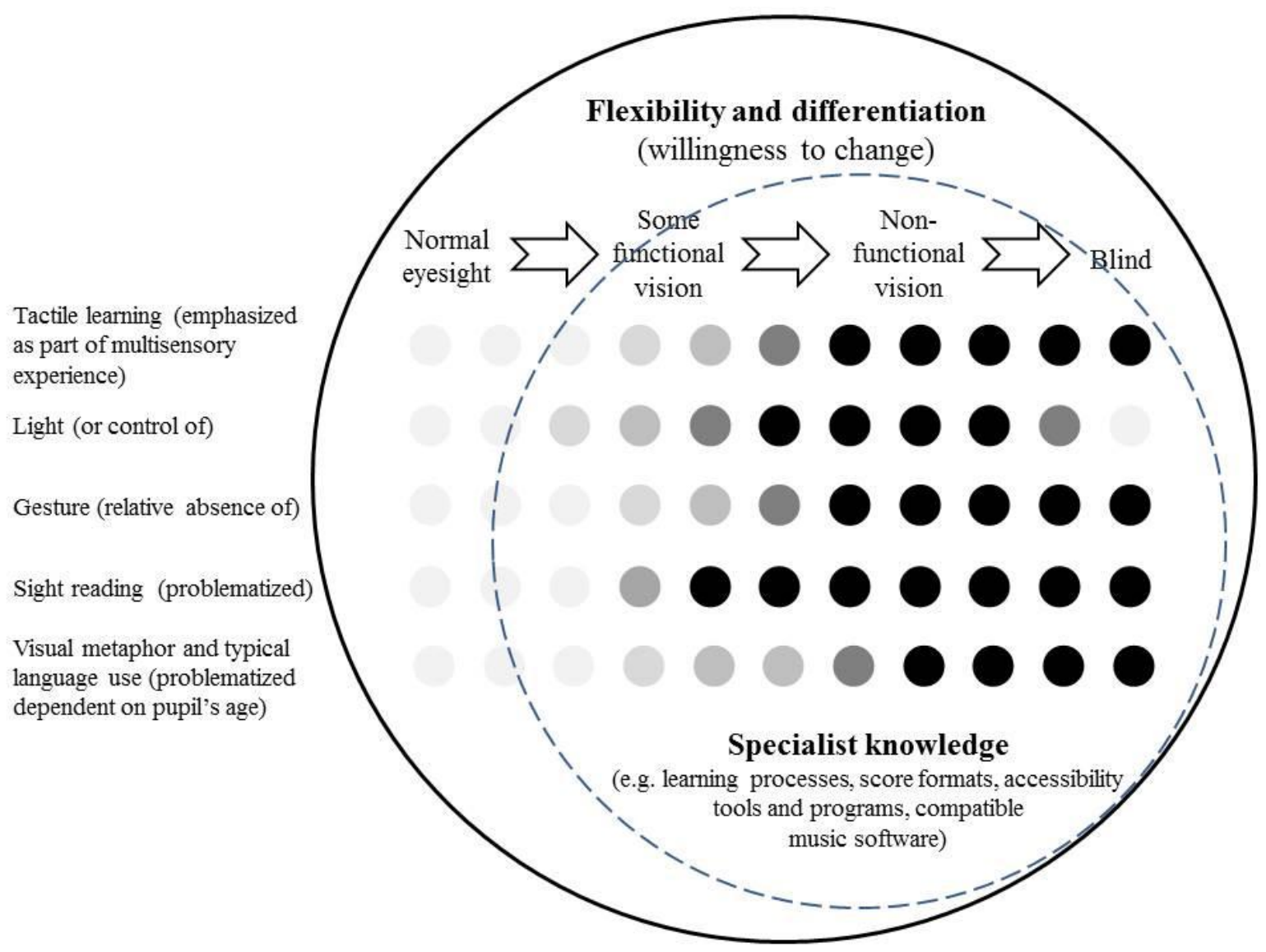

Figure 1 illustrates how themes discussed thus far may relate to pedagogy and correspond to sight condition. Where the points in the diagram are darker (dark grey to black), the themes to the left of the figure are emphasized as concerns, with sight condition across the top (normal eyesight to blind, i.e. with no light perception). The region within the dotted line indicates the need for specialist knowledge of teaching to various extents. We consider flexibility and differentiation a normal requirement of any teacher, whether or not they work with visuallyimpaired students.

\section{Medium and musical approach: The issue of notation}

Music education has for well over a century focussed on stave notation (or in some cases another written form such as graphic notation or tablature), as the main means of musical transmission. In many traditions, whether for sighted or visually-impaired learners, particularly specialist instrumental tuition, notation is often used as the only means of 
transmission. In mainstream classrooms, although there has been an upsurge in interest in ear-playing techniques in the last couple of decades, ${ }^{18}$ we found that where specialist provision was available to our participants, there had tended to be an emphasis on notated ways of transmitting music. This again surprised us somewhat since it might seem "obvious" to emphasise ear playing if one is teaching a student with a visual impairment. Undoubtedly the causes of this tendency are complex, and have as much to do with the history of teaching and teaching qualifications as anything else, as well as the capacity of the visually impaired to access learning through technology (see e.g. Todd, 1992; Aitken, 1997). In this section we focus on some of the issues surrounding the transmission and acquisition of notation-based music amongst visually-impaired learners and their teachers in classrooms and instrumental contexts.

\section{Braille music}

An instrumentalist working from Braille notation iterates back and forth between touching and, separately, performing the medium, a process of "chunking"; this is a laborious process of absorbing small parts at first, until locked into the procedural memory (also see Anderson's “adaptive control of thought" model, e.g. Anderson, 1983, 1990, 1993, Anderson \& Lebiere, 1998). ${ }^{19}$ Many interviewees emphasised that Braille is a difficult medium to learn. Accuracy is sometimes gained through cross-referencing with recordings, and the use of commonplace technologies such as audio recordings, YouTube, and so on, which of course are also components of ear playing. It is likely this approach to gaining accuracy is used more often by visually-impaired notation players using Braille, than those who are sighted and using print notation, although we have no data to compare the two groups as yet.

For those learning from Braille music, there is the added time burden of, firstly, acquiring scores from translation services which produce it from print originals (e.g. Golden Chord, Hereford, UK) or libraries, and secondly, memorisation in the absence of the capacity

\footnotetext{
${ }^{18}$ See e.g. Green (2001, 2008, 2012), Hallam, Creech, Sandford, Rinta and Shave (2008), D'Amore (2011), Jeanneret, McLennan and Stevens-Ballenger (2011), Wright (2011, 2012), Gower (2012), Narita (2012), O'Neill and Bespflug (2012), Chua (2013a, b), Chua and Ho (2013a, b), Costes-Onish (2013), Ho (2013a, b), and McPhail (2013). In relation to the instrumental sphere, see e.g. Baker (2013), Baker and Green (2013), Green (2014), Varvarigou (2014), and Varvarigou and Green (2014). ${ }^{19} \mathrm{We}$ are not suggesting that a fully-sighted person cannot develop procedural musical knowledge in the same way but, for some sight-impaired or severely sight-impaired people, this is their only way of acquiring it when using a score, whether enlarged or modified stave notation, or Braille music. The nature of that acquisition is no less multimodal, too, and both involve memory of course. The key difference is the primacy of the eye for the sighted person whilst performing from a score.
} 
to sight read. Many interviewees noted how the accessibility of Braille music, its acquisition and learning time problematized participation particularly in musical contexts and genres that relied heavily on sight reading in rehearsals, or where digesting large quantities of printed repertoire was required (e.g. the symphony orchestra).

The work of innovators like Lydia Machell is easing access to the medium. Lydia works with cooperating music publishers' digital production files; she has created software that outputs these as digital Braille (e.g. .brf [Braille Ready Format]), which can be purchased and downloaded from the Prima Vista Braille Music Services website. ${ }^{20}$ It can, subsequently, be embossed or read on an electronic device by the consumer (e.g. a Braille note-taker). We sensed, though, talking to people in countries as far apart as Brazil and Malaysia, that getting Braille music from libraries was particularly difficult, and available scores and parts were limited. We ponder, then, if wider accessibility to specialist services and support is correlated to geographical location, with rural areas most challenged, in terms of access to a wide variety of specialist support and services.

There were some passionate arguments about the place of Braille music. One respondent said it was “....as important for visually-impaired people to be musically literate as it is for sighted people" (Amanda, singer, pianist, flautist, accordionist and music workshop presenter, severely sight-impaired; interview, UK). Another said learning Braille music was about the "right to literacy" (Anon. questionnaire response, Canada). Others, though, did not read Braille music at all and saw no need for it; some opted for ear learning, or low vision learners used enlarging stave notation with photocopiers or software magnification with PCs, hand-held magnifiers in rehearsals, or modified stave notation on tablets.

The need, or desire to read some form of notation rests on a mix of educational background, values and chosen musical genre. Recent research has shown the benefits (e.g. increased aural development and student motivation) of importing informal learning and ear playing from popular and other vernacular musicians' learning practices into the school curriculum and instrumental tuition (see Note 18). Furthermore, the quantity of musics globally that are acquired through oral traditions dwarfs Western classical music - it is all too easy to over-play notation as essential to all musical understanding. But conversely its absence inevitably closes doors to many musical genres and opportunities. As Green explains, informal and ear-playing strategies brought into formal education settings were

\footnotetext{
${ }^{20}$ The Prima Vista Braille Music Services website can be found at www.primavistamusic.com/ (accessed 29 September 2014).
} 
never "designed in any way to replace existing approaches that teachers already use. Rather, they are intended to run alongside or in-between whatever other work teachers are already doing" (Green, 2014, p. xii; also see e.g. Green, 2008, Chapter 8); and this sentiment is undoubtedly shared by others working in this field across the board (see Note 18).

Our questionnaire revealed that $28.80 \%$ (55 respondents) neither read Braille music nor literary Braille, but 52.36\% (100) could read Braille music even if they did not use it. This seems a particularly high figure given published questionnaires indicating only $3-4 \%$ of visually-impaired children use literary Braille (e.g. Keil \& Clunies-Ross, 2002; Morris \& Smith, 2008 on children age 5-16 years). We did not find evidence to support a downward trend in Braille music literacy across time, due to factors like mainstreaming children in education or inadequate access to Braille music specialists, as suggested by Wesseling (2004) and some of our respondents. A severely sight-impaired interviewee reflected, for example:

If you're not going to learn print notation, you should learn Braille [music] notation; but we know that just doesn't happen, and it doesn't happen for a lot of reasons. You've got a lot of teaching assistants who aren't confident in the literary Braille let alone wanting to teach Braille music. You've lost that network of special school teachers, where they've got five kids in a class who want to learn rather than one kid every five years. So there are a lot of factors that have made it a lot more difficult to learn Braille music... (Jonathan, woodwind player, severely sight-impaired; interview, UK)

However, the problems associated with sight reading are not limited to Braillists: for some experiencing sight loss after having previously been sighted and working with stave notation, sight reading becomes challenging in new ways, with the increasing enlargement of stave notation parts (and subsequent deterioration of image quality, particularly from older print sources). The development of tablet technologies, with enlarged digital stave notation prompted forward by foot pedals like Music Reader ${ }^{21}$ and modified stave notation ${ }^{22}$ (e.g.

\footnotetext{
${ }^{21}$ For information on "Music Reader", refer to http://www.musicreader.net/ (accessed 26 June 2014). It is software that runs on Apple's iPad, and Windows laptops, tablets and desktops, which allows scores to be scanned becoming scalable PDFs of scores that can, then, be moved forward with a foot pedal.

22 "Modified stave notation" refers to stave notation whereby elements such as stave lines, note-heads, or dots are modified in size or thickness, or elements are altered in colour (e.g. the background).

MuseScore software can produce such adaptations; we met one of its developers, Thomas Bonte at the 2014 UK Association of Accessible Formats (UKAAF) conference held at the RNIB, London.
} 
MuseScore software) are helping. Nonetheless, several interviewees highlighted that this did not allow the "eye to sweep across the score" in quite the same way. In a sense, then, the absence of sight implies an emphasis placed on ear playing and memorisation, as well as improvisation of course, whilst reading and especially sight reading are de-emphasised.

\section{Concluding thoughts}

Our engagement with this international visually-impaired community found members to be extremely diverse in musical participation in adulthood, boldly challenging barriers thrown up and flagged by our respondents concerning say, problems with the teaching they received, or with score media and the acquisition of music from them. We posed the statement "Discrimination limits the ability of visually-impaired people to engage with music throughout their lives (as learners, amateurs or professionals)" (143 questionnaire responses) which produced a mean of $3.43(\mathrm{SD}=1.08)$ or a measure of "Agreement". Yet these people had traversed pathways from childhood to adulthood to become rich musical-cultural participants.

So, too, as "challengers of barriers" did several producers of electronic music find programmers who created software plug-in solutions for inaccessible music software (for notation, recording or MIDI sequencing), or they created plug-ins themselves. In the 1990s, the development of "Sibelius Speaking", a bridge between the JAWS screen reader and this notation software, opened up new opportunities for visually-impaired musicians, and yet many applications (e.g. Digital Audio Workstations for music production, notation programs, etc.) have remained beyond reach due to incompatibility with accessibility software. ${ }^{23}$

With visually-impaired children learning in schools, the onus is on music teachers to have knowledge of accessibility technologies, their compatibility with music technologies, and workable digital formats of scores (according to specific learning approaches) where required. But this represents a troubling situation raising questions about the breadth of knowledge needed by a school's music teacher, and what is feasible, amid a maelstrom of software development and shifting compatibility. We can only ponder those visuallyimpaired children and adults who may have fallen unnecessarily by the musical wayside,

\footnotetext{
${ }^{23}$ Apple programs, for instance, like Logic (music production software) were, until recently, inaccessible to text-to-speech software. We now see the emergence of touchscreen technologies that are problematical for severely sight-impaired user.
} 
locked out of particular areas of musical learning across the life-course (or who will be locked out). We certainly found that there was some disquiet about educational opportunity, including schooling as remembered, and "mainstreaming" as it is now, plus the knowledge and skills of sighted educators within mainstream schools. Florian (2008) suggests that it is only through an examination of "...the things that teachers can do..." that we will arrive at an understanding of the concept of inclusion. Hodgson (1985a) observes that educating the visually impaired in the mainstream is "...not a cheap option..." as it "...demands cooperation between the specialist and class teacher..." (p. 35). Our findings on schools and educators do need to be triangulated with visually-impaired children's perspectives, referencing both attendees at today's "mainstream" and special schools. We make no claim, also, that the notions we present contribute to a single "correct" vision of current educational policy or organization; indeed, that was far from our intention with this research. Instead, we wished to unearth the multifaceted and sometimes conflicting ways "insiders" within this community interpret musical learning within schooling. At times too, respondents commented on contexts with which they had no direct experience as pupils; however, the large volume of qualitative data from our questionnaires and interviews permitted the triangulation of such opinions with those of respondents who had. Regardless of the type of schooling they received, though, members of vested social groups should have the democratic right to comment on matters of education at large as they understand it. What these viewpoints do illustrate sharply, then, is that longstanding debate on school types, integration, independence, educators and access to learning continues within this group (for examples of the debates and issues, see e.g. Morgan, 1977; Hodgson, 1985a, b; Buultjens, 1986; Thomas \& Jackson, 1986; Alan Dobbins \& de la Mere, 1993; Stokes, 1993; Talbot \& Farbey, 1997; Talbot, 2002; Pavey, Douglas, McLinden \& McCall, 2003; Alghazo \& Nagger Gaad, 2004; Rogers, 2007; Florian, 2008; Hess, 2010; Deng \& Poon-McBrayer, 2012; Lee \& Low, 2014).

It is true that the musicians with whom we liaised were well networked. They held a common identity as members of what might be regarded as a "disabled musical community", through e-bulletin lists on music (e.g. Music Talk, the e-mail list of the National Association of Blind Musicians [NABM, US]), musical societies and charities, "disability ensembles", social gatherings, and common interests and problems. Some experiences, like the accessibility of Braille music with its ramifications for learning processes and contexts and, thus, participation in sighted contexts, are generalizable across countries. As mentioned, we are aware that we cannot make worldwide generalizations due to limited data. Differences in social support and care mechanisms, and in schooling and the historical changes therein, 
cloud any such observations or, indeed, accurate worldwide comparisons. Regardless, our findings and the "voices" that have been allowed to resonate are, we feel, intriguing. As Hatch and Wisniewski (1995) argue, the accessibility of life history reporting can produce “...'findings' that have more practical value for wider populations of readers than other forms of qualitative research" (p. 117). Additionally, although equality is affirmed in law, as Crichton (1992) astutely writes “...there are often problems, practical and otherwise, in going from policy or intent to disabled people's actual access to a broad range of music experience" (p. 211).

We were limited by the number of specialist teachers we consulted on pedagogical principles, but, nonetheless, we found some useful reflections that could be taken and tested in situ by other music practitioners even so. With music teaching occurring in schools, the private instrumental teaching studio, and in a range of community settings, but bearing in mind visual impairment is a relatively low incidence Special Educational Need, all this also raises questions about the training and awareness needed by, say, music degree students who, as part of a "portfolio career" (Bennett, 2008), may well teach; not to mention those who are training to become specialist music teachers. Perhaps awareness can be raised in "reflective practice" exercises by in-service and future music educators (on "reflective practice" read: Schön, 1983, 1987; Loughran, 2002; Titus \& Gremler, 2010; Burwell, 2012). In relation not only to visual impairment but "disability", or "different abilities" in general, this could take music undergraduates in conservatoires and university music departments along a critical chain from the "insider" views of the differently-abled to the autonomous development of practice; that is, teaching of which they have very deep understanding and considerable ownership. It would bid deeper reflection on special educational needs and necessary differentiation in music classrooms or other contexts. Undoubtedly, this paper is a "scoping" exercise in that, although it has some imponderables and pitfalls, we hope it provides an "insider" lens on a specialist area of music education. In scoping visually-impaired musical participation globally, it has come across many potential further lines of enquiry and, most potently we believe, it bids us to consider matters of educational equality, inclusion and access, as well as the potential benefits of musical participation for visually-impaired children and adults.

\section{Acknowledgements}


We are extremely grateful for the time, interest and openness of all our respondents. We also wish to acknowledge the financial support of the Arts and Humanities Research Council, UK (Grant ref. AH/K003291/1) in addition to the guidance of our advisory panel: Peter Bosher (Soundlinks Ltd.); Jackie Clifton MBE (Royal College of Music, London); Dr Anthony Gritten and Julian West (Royal Academy of Music, London); Kevin Kern; Lord Colin Low of Dalston CBE, James Risdon and Sally Zimmermann (Royal National Institute of Blind People); Lydia Machell (Prima Vista Braille Music Services); and Vasuki Sivagnanavel (Royal Eye Unit, Kingston Hospital, London). We also wish to thank Robert Mitchell (Institute of Education, University of London) for administrative support relating to this project and Dr Maria Vraka-Martone for transcribing our audio data.

\section{References}

Aitken, S. (1997) “Access through technology.” In H. Mason and S. McCall (Eds.), Visual Impairment: Access to Education for Children and Young People, 187-195. Abingdon, Oxfordshire: David Fulton Publishers.

Alan Dobbins, D. and de la Mere, T. (1993) "Efficacy of special education provision for primary school pupils with serious visual impairment." British Journal of Visual Impairment, 11(2), 49-54.

Aldridge, A. and Levine, K. (2001) Questioning the Social World: Principles and Practice in Questionnaire Research (Understanding Social Research; A. Bryman, Series Ed.). Buckingham, UK: Open University Press.

Alghazo, E. M. and Nagger Gaad, E. E. (2004) "General education teachers in the United Arab Emirates and their acceptance of the inclusion of students with disabilities." British Journal of Special Education, 31(2), 94-99.

Anderson, J. (1983) The Architecture of Cognition. Cambridge, MA: Harvard University Press. 
Anderson, J. (1990) The Adaptive Character of Thought. Hillsdale, NJ: Lawrence Erlbaum Associates.

Anderson, J. (1993) Rules of Mind. Hillsdale, NJ: Lawrence Erlbaum Associates.

Anderson, J. and Lebiere, C. (1998) The Atomic Components of Thought. Mahwah, NJ: Lawrence Erlbaum Associates.

Argyle, M. (1988) Bodily Communication (2nd ed.). London: Routledge.

Armstrong, P. (1987) Qualitative Strategies in Social and Educational Research: The Life History Method in Theory and Practice (Newland Paper, No. 14). Hull, UK: School of Adult and Continuing Education, University of Hull.

Atkin, M.-M., Holbrook, C., MacCuspie, A., Mamer, L. McConnell, D., McConnell, R., Muller, C., Nagel, K., Rannelli, P., Sitar, D. and Studholme, L. (2003) Canadian National Standards for the Education of Children and Youth who are Blind or Visually Impaired, including those with Additional Disabilities. Toronto, Ontario, Canada: National Coalition for Vision Health.

Atkinson, R. (1998) The Life Story Interview (Qualitative Research Methods Series, No. 44). Thousand Oaks, CA: Sage.

Atkinson, R. (2001) “The life story interview.” In J. F. Gubrium and J. A. Holstein (Eds.), Handbook of Interview Research: Context and Method, 121-40. Thousand Oaks, CA: Sage.

Baker, D. (2005a) “Music service teachers' life histories in the United Kingdom with implications for practice.” International Journal of Music Education, 23(2): 251-66.

Baker, D. (2005b) "Peripatetic music teachers approaching mid-career: A cause for concern?" British Journal of Music Education, 22(2): 141-53.

Baker, D. (2005c) Voices in concert: Life histories of peripatetic music teachers. $\mathrm{PhD}$ dissertation, Institute of Education, University of Reading. 
Baker, D. (2006) “Life histories from a music service: The past in inductees' present." British Journal of Music Education, 23(1): 39-50.

Baker, D. (2013) "Informal learning and the instrumental lesson: Teacher and student evaluations of the Ear Playing Project (EPP)." In M. Stakelum (Ed.), Developing the Musician: Contemporary Perspectives on Teaching and Learning (SEMPRE Studies in the Psychology of Music), 291-309. Surrey, UK: Ashgate.

Baker, D. and Green, L. (2013) "Ear playing and aural development in the instrumental lesson: Results from a 'case-control' experiment.” Research Studies in Music Education, $35(2), 141-159$.

Baker, D. (2014) "Visually-impaired musicians' narrative insights: Childhood, lifelong learning and musical participation.” British Journal of Music Education, 31(2): 113-135.

Barrett, M. and Stauffer, S. (Eds.) (2009) Narrative Inquiry in Music Education: Troubling Certainty. Heidelberg: Springer.

Barrett, M. and Stauffer, S. (Eds.) (2012) Narrative Soundings: An Anthology of Narrative Inquiry in Music Education. Heidelberg: Springer.

Bathmaker, A.-M. (2010) “Introduction.” In A.-M. Bathmaker and P. Harnett (Eds.), Exploring Learning, Identity and Power through Life History and Narrative Research, 1-10. Abingdon, Oxfordshire, UK: Routledge.

Batterson, J. A. (1998) Blind Boone: Missouri’s Ragtime Pioneer. Columbia, MO: University of Missouri Press.

Bennett, D. (2008) Understanding the Classical Music Profession: The Past, the Present and Strategies for the Future. Farnham, Surrey, UK: Ashgate.

BERA (British Educational Research Association) (2011) Ethical Guidelines for Educational Research. London: BERA. 
Bertaux, D. (Ed.) (1981) Biography and Society: The Life History Approach in the Social Sciences (Studies in International Sociology, No. 23). Beverly Hills, CA: Sage.

Bertaux, D. and Kohli, M. (1984) "The life story approach: A continental view." Annual Review of Sociology, 10: 215-37.

BPS (British Psychological Society) (2010) Code of Human Research Ethics. Leicester, UK: BPS.

Burnard, P. (1999) Into different worlds: Children's experience of musical improvisation and composition. PhD dissertation, School of Education, University of Reading.

Burnard, P. (2003) "How musical are you? Examining the discourse of derision in music education.” In S. Leong (Ed.), Musicianship in the 21st Century: Issues, Trends and Possibilities, 28-38. Sydney: Australia Music Centre.

Burnard, P. (2004) "Using critical incident charting for reflecting on musical learning." Mountain Lake Reader, (Spring issue): 7-13.

Burwell, K. (2012) Studio-Based Instrumental Learning (SEMPRE Studies in the Psychology of Music). Farnham, Surrey, UK: Ashgate.

Buultjens, M. (1986) "Parental perceptions of special educational provision for the visually impaired." British Journal of Visual Impairment, 4(2), 65-68.

Casey, K. (1993) I Answer with My Life: Life Histories of Women Teachers Working for Social Change. New York, NY: Routledge.

Chua, S. (2013a). "Informal learning for song writing. In S. L. Chua and H. P. Ho (Eds.), Connecting the Stars: Essays on Student-Centric Music Education, 87-97. Singapore: Singapore Teachers' Academy for the Arts, Ministry of Education. 
Chua, S. (2013b). STOMPing up musical engagement the non-formal and informal way. In S. Chua and H. Ho (Eds.), Connecting the Stars: Essays on Student-Centric Music Education, 127-142. Singapore: Singapore Teachers’ Academy for the Arts, Ministry of Education.

Chua, S. and Ho, H. (2013a) "Connecting findings, reflections and insights: Studentcentricity musically, creatively." In S. Chua and H. Ho (Eds.), Connecting the Stars: Essays on Student-Centric Music Education, 143-154. Singapore: Singapore Teachers' Academy for the Arts, Ministry of Education.

Chua, S. and Ho, H. (2013b) "Piloting informal and non-formal approaches for music teaching in five secondary schools in Singapore: An introduction.” In S. Chua and H. Ho (Eds.), Connecting the Stars: Essays on Student-Centric Music Education, 52-65. Singapore: Singapore Teachers' Academy for the Arts, Ministry of Education.

Clark, A. and Murphy, F. (1998) "Teaching music to the visually impaired student in a standard school setting." British Journal of Visual Impairment, 16(3), 117-122.

Cohen, L., Manion, L., and Morrison, K. (2000) Research Methods in Education (5th ed.). London: Routledge and Falmer Press.

Costes-Onish, P. (2013) "Negotiating the boundaries of formal and informal learning." In S. Chua and H. Ho (Eds.), Connecting the Stars: Essays on Student-Centric Music Education, 98-109. Singapore: Singapore Teachers’ Academy for the Arts, Ministry of Education.

Crichton, L. (1992) “Music for everyone?” British Journal of Music Education, 9(3): 211-15.

D’Amore, A. (Ed.) (2011). Musical Futures: An Approach to Teaching and Learning (2nd ed.). London: Paul Hamlyn Foundation.

De Ferranti, H. (2009) The Last Biwa Singer: A Blind Musician in History, Imagination and Performance. Ithaca, NY: Cornell University Press.

Deng, M. and Poon-McBrayer, K. F. (2012) "Reforms and challenges in the era of inclusive education: The case of China." British Journal of Special Education, 39(3), 117-112. 
Denicolo, P. and Pope, M. (1990) “Adults learning - teachers thinking.” In C. Day, M. Pope and P. Denicolo (Eds.), Insight into Teachers' Thinking and Practice, 155-69. Basingstoke, UK: Falmer Press.

Denicolo, P. and Pope, M. (2001) Transformative Professional Practice: Personal Construct Approaches to Education and Research. London: Whurr.

DfES (Department for Education and Skills) (2001a) Inclusive Schooling: Children with Special Educational Needs. Nottingham, UK: DfES Publications.

DfES (Department for Education and Skills) (2001b) Special Educational Needs: Code of Practice (Ref. DfES/581/2001). Nottingham, UK: DfES Publications.

Dimatati, M., Heaton, P., Pring, L., Downing, J., and Ockelford, A. (2012) “Exploring the impact of congenital visual impairment on the development of absolute pitch using a new online assessment tool: A preliminary study." Psychomusicology: Music, Mind and Brain, 22(2): 129-33.

Dollase, R. H. (1992) Voices of Beginning Teachers: Visions and Realities. New York, NY: Teachers College Press.

Downey, J. (2009) "Informal learning in music in the Irish secondary school context." Action, Criticism and Theory in Music Education, 8(2), 47-60.

Elbaz, F. (1990) "Knowledge and discourse: The evolution of research on teacher thinking." In C. Day, M. Pope and P. Denicolo (Eds.), Insight into Teachers' Thinking and Practice, 15-42. Basingstoke, UK: Falmer Press.

Feichas, H. (2010) "Informal music learning practices as a pedagogy of integration in Brazilian Higher Education.” British Journal of Music Education, 27(1), 47-58.

Finney, J. and Philpott, C. (2010) "Student teachers appropriating informal pedagogy." British Journal of Music Education, 27(1), 7-19. 
Florian, L. (2008) "Special or inclusive education: Future trends." British Journal of Special Education, 35(4), 202-208.

Flyvbjerg. B. (2006) "Five misunderstandings about case-study research.” Qualitative Inquiry, 12(2): 219-45.

Folkestad, G. (2006) "Formal and informal learning situations or practices versus formal and informal ways of hearing." British Journal of Music Education, 23(2), 135-145.

Fontana, A. (2003) "Postmodern trends in interviewing." In J. Gubrium and J. Holstein (Eds.), Postmodern Interviewing, 51-65. Thousand Oaks, CA: Sage.

Fuqua, C. S. (2011) Alabama Musicians: Musical Heritage from the Heart of Dixie. Charleston, SC: The History Press.

Gillham, B. (2007) Developing a Questionnaire (2nd ed.). London: Continuum.

Glesne, C. E. and Peshkin, A. (1992) Becoming Qualitative Researchers: An Introduction. New York, NY: Longman.

Gower, A. (2012) "Integrating informal learning approaches into the formal learning environment of mainstream secondary schools in England." British Journal of Music Education, 29(1), 13-18.

Green, L. (2001) How Popular Musicians Learn: A Way Ahead for Music Education. Farnham, UK: Ashgate.

Green, L. (2008) Music, Informal Learning and the School: A New Classroom Pedagogy. Farnham, UK: Ashgate.

Green, L. (2012) “Informal learning and aural learning in the instrumental music lesson: Findings from a research-and-development pilot project.” In L. Vakeva, \& S. Karlsen (Eds.), 
Future Prospects for Music Education: Corroborating Informal Learning Pedagogy, 161-96). Newcastle, UK: Cambridge Scholars Press.

Green, L. (2014) Hear, Listen, Play! How to Increase Your Students' Aural, Improvisation and Performance Skills. New York, NY: Oxford University Press.

Gregory, I. (2003) Ethics in Research (Continuum Research Methods Series, R. Andrews, Ed.). London: Continuum.

Gritten, A. and King, E. (2006) “Introduction.” In A. Gritten and E. King (Eds.), Music and Gesture (p. xx). Aldershot, Hampshire, UK: Ashgate.

Groemer, G. (2012) The Spirit of Tsugaru - Blind Musicians, Tsugaru-Jamisen and the Folk Music of Northern Japan (with the Autobiography of Takahashi Chikuzan) (2nd ed.). Aomori Prefecture, Japan: Tsugaru Shobo Hirosaki.

Guba, E. and Lincoln, Y. (1989) Fourth Generation Evaluation. Newbury Park, CA: Sage.

Hallam, S., Creech, A., Gaunt, H., Pincas, H., Varvarigou, M., and McQueen, H. (2011) Music for Life Project: The Role of Participation in Community Music Activities in Promoting Social Engagement and Wellbeing in Older People (newsletter, November). Sheffield, UK: Department of Sociology, University of Sheffield (New Dynamics of Ageing Research Programme).

Hallam, S., Creech, A., Pincas, H., Varvarigou, M., McQueen, H., and Gaunt, H. (2010) Music for Life Project: Promoting Social Engagement and Wellbeing in Older People through Community Supported Participation in Musical Activities (newsletter, June). London: Institute of Education, University of London (New Dynamics of Ageing Research Programme).

Hallam, S., Creech, A., Sandford, C., Rinta, T., \& Shave, K. (2008) Questionnaire of Musical Futures: A Report from Institute of Education, University of London for the Paul Hamlyn Foundation. Retrieved from http://www.academia.edu/2848671/Questionnaire_of_Musical_Futures_A_Report_from_Inst 
itute_of_Education_University_of_London_for_the_Paul_Hamlyn_Foundation (accessed 23 June 2014).

Hamilton, R., Pascual-Leone, A., and Schlaug, G. (2004) “Absolute pitch in blind musicians." Neuroreport: Auditory and Vestibular Systems, 15(5): 803-6.

Harrah, M. (2004) Blind Boone: Piano Prodigy. Minneapolis, MN: Carol Rhoda Books.

Hatch, J. A., and Wisniewski, R. (1995) "Life history and narrative: Questions, issues, and exemplary works.” In J. A. Hatch and R. Wisniewski (Eds.), Life History and Narrative (Qualitative Studies, No. 1), 113-35. London: Falmer Press.

Hess, I. (2010) "Visually impaired pupils in mainstream schools in Israel: Quality of life and other associated factors." British Journal of Visual Impairment, 28(1), 19-33.

Ho, H. (2013a) "Connecting the curricular and co-curricular through formal and non-formal teaching." In S. Chua and H. Ho (Eds.), Connecting the Stars: Essays on Student-Centric Music Education, 110-126. Singapore: Singapore Teachers' Academy for the Arts, Ministry of Education.

Ho, H. (2013b) "Rollin' in at the deep end: Choice, collaboration and confidence through informal learning with the guitar." In S. Chua and H. Ho (Eds.), Connecting the Stars: Essays on Student-Centric Music Education, 66-85. Singapore: Singapore Teachers' Academy for the Arts, Ministry of Education.

Hodgson, A. (1985a) "How to integrate the visually impaired." British Journal of Special Education, 12(1), 35-37.

Hodgson, A (1985b) "Meeting special needs in mainstream classrooms." British Journal of Special Education, 12(3), 117-118.

Holstein, J. and Gubrium, J. (1995) The Active Interview. Thousand Oaks, CA: Sage. 
Holstein, J. and Gubrium, J. (1997) “Active interviewing.” In D. Silverman (Ed.), Qualitative Research: Theory, Method and Practice, 113-29. London: Sage.

Holstein, J. and Gubrium, J. (2003) “Active Interviewing.” In J. Gubrium and J. Holstein (Eds.), Postmodern Interviewing, 67-80. Thousand Oaks, CA: Sage.

Huberman, M. (1993) The Lives of Teachers (J. Neufeld, Trans.). New York, NY: Teachers College Press (Columbia University).

Huberman, M. and Marti, J. (1993) “Beginning teaching.” In A. Hargreaves (Ed.), The Lives of Teachers, 194-213. New York, NY: Teachers College Press (Columbia University).

IDEA (Individuals with Disabilities Education Act) (1997) Refer to http://idea.ed.gov/ (accessed 23 June 2014). This relates to the education of US citizens from 3 to 21 years of age. It was signed into law by President George H. W. Bush in 1990.

Jaffurs, S. (2004) "The impact of informal music learning practices in the classroom, or how I learned how to teach from a garage band." International Journal of Music Education, 22(3), 189-200.

Jeanneret, N., McLennan, R., and Stevens-Ballenger, J. (2011) Musical Futures: An Australian Perspective (Findings from a Victorian Pilot Study). Melbourne, Australia: Graduate School of Education, University of Melbourne.

Jones, K. (2011) “The practice of quantitative methods.” In B. Somekh and C. Lewin (Eds.), Theory and Methods in Social Research (2nd ed.), 201-11). London: Sage.

Karlsen, S. (2010) "Boom-town music education/authenticity: Informal music learning in Swedish postcompulsory music education.” British Journal of Music Education, 27(1), 3546.

Keil, S. (2012a) RNIB Questionnaire of VI Services in England and Wales 2012: Report for England. London: Royal National Institute of Blind People. 
Keil, S. (2012b) The Reasons Blind and Partially Sighted Children and Young People Need Specialist Educational Provision (Research Briefing). London: Royal National Institute of Blind People.

Keil, S. and Clunies-Ross, S. (2002) Teaching Braille to Children. London: Royal National Institute of Blind People.

Kirkwood, R. and McCall, S. (1997) “Educational provision.” In H. Mason and S. McCall (Eds.), Visual Impairment: Access to Education for Children and Young People, 13-20. Abingdon, Oxfordshire: David Fulton Publishers.

Kononenko, N. (1998) Ukrainian Minstrels: And the Blind Shall Sing. New York, NY: M. E. Sharpe.

Lababidi, L. and El-Arabi, N. (2002) Silent No More: Special Needs People in Egypt. Cairo, Egypt: American University in Cairo Press.

Lee, L. W. and Low, H. M. (2014) “The evolution of special education in Malaysia.” British Journal of Special Education, 41(1), 42-58.

Lee, R. and Fielding, N. (2004) “Tools for qualitative data analysis.” In M. Hardy and A. Bryman (Eds.), Handbook of Data Analysis, 529-46. London: Sage. Lewis, O. (1961) The Children of Sánchez. New York, NY: Vintage. Lines, D. (2009) "Exploring the contexts of informal learning." Action, Criticism and Theory in Music Education, 8(2), 1-6.

Loughran, J. J. (2002) "Effective reflective practice: In search of meaning in learning about teaching." Journal of Teacher Education, 53(1): 33-43.

Lubet, A. (2011) Music, Disability, and Society. Philadelphia, PA: Temple University Press. 
MacLeod, V. (1987) "The teaching of music to primary children in schools for the visually handicapped compared with mainstream schools." British Journal of Visual Impairment, 5(3), 99-101.

Mans, M. (2009) "Informal learning and values." Action, Criticism and Theory in Music Education, 8(2), 79-93.

McCall, S. (1997) “Historical perspectives.” In H. Mason and S. McCall (Eds.), Visual Impairment: Access to Education for Children and Young People, 3-12. Abingdon, Oxfordshire: David Fulton Publishers.

McPhail, G. (2013) "Informal and formal knowledge: The curriculum conception of two rock graduates.” British Journal of Music Education, 30(1), 43-57.

Melcher, D. and Zampini, M. (2011) "The sight and sound of music: Audiovisual interactions in science and the arts." In F. Bacci and D. Melcher (Eds.), Art and the Senses, 265-92. Oxford, UK: Oxford University Press.

Miles, M. and Huberman, M. (1994) Qualitative Data Analysis: An Expanded Sourcebook (2nd ed.). Thousand Oaks, CA: Sage.

Miller, O. and Ockelford, A. (2005) Visual Needs (SEN Series). London: Continuum.

Morgan, G. (1977) “Integration v. segregation in Ontario.” British Journal of Special Education, 4(1), 18-21

Morris, M. and Smith, P. (2008) Educational Provision for Blind and Partially-Sighted Children and Young People in Britain: 2007. London: Royal National Institute of Blind People.

Munro, P. (1998) Subject to Fiction: Women Teachers' Life History Narratives and the Cultural Politics of Resistance. Buckingham, UK: Open University Press. 
Myers, D. E. (1995) "Lifelong learning: An emerging research agenda for music education.” Research Studies in Music Education, 4(1): 21-7.

Myers, D. E. (2008) "Lifespan engagement and the question of relevance: Challenges for music education research in the twenty-first century." Music Education Research, 10(1): 114.

Narita, F. (2012). Music education in the Open University of Brazil: Informal learning practices. ICT in the Musical Field, 3(2): 43-48.

Ockelford, A. (2000) "Music in the education of children with severe or profound learning difficulties: Issues in current UK provision, a new conceptual framework, and proposals for research." Psychology of Music, 28(2): 197-217.

Ockelford, A. (2007) In the Key of Genius: The Extraordinary Life of Derek Paravicini. London: Hutchinson.

Ockelford, A. (2008) Music for Children and Young People with Complex Needs. Oxford, UK: Oxford University Press.

Ockelford, A. and Matawa, C. (2009) Focus on Music 2: Exploring the Musical Interests and Abilities of Blind and Partially-Sighted Children with Retinopathy of Prematurity. London: Institute of Education, University of London.

Ockelford, A., Pring, L., Welch, G. F., and Treffert, D. (2006) Focus on Music: Exploring the Musical Interests and Abilities of Blind and Partially Sighted Children with Septo-Optic Dysplasia. London: Institute of Education, University of London.

Ockelford, A., Welch, G. F., and Zimmermann, S.-A. (2002) "Focus on practice: Music education for pupils with severe or profound and multiple difficulties - current provision and future need.” British Journal of Special Education, 29(4): 178-82.

O’Neill, S., \& Bespflug, K. (2012). Musical Futures comes to Canada: Engaging students in real-world music learning. Canadian Music Educator, 53(2), 25-34. 
Ottenberg, S. (1996) Seeing with Music: The Lives of Three Blind African Musicians. Washington, DC: University of Washington Press.

Pavey, S., Douglas, G., McLinden, M. and McCall, S. (2003) "An investigation into the mobility and independence needs of children with visual impairment. Part 1: The development of a mobility and independence curriculum framework." British Journal of Visual Impairment, 21(1), 4-9.

Pope, M. L. and Denicolo, P. M. (1993) “The art and science of constructivist research in teacher thinking." Teaching and Teacher Education, 9(5/6): 529-44.

RNIB (Royal National Institute of Blind People) (2013a) Key Statistics on the Number of Blind and Partially-sighted Children and Young People in England (Research Briefing). London: RNIB.

RNIB (Royal National Institute of Blind People) (2013b) Teaching Music to Students with Vision Impairment (Effective Practice Guide). London: RNIB.

Roberts, B. (2002) Biographical Research (Understanding Social Research Series, A. Bryman, Ed.). Buckingham, UK: Open University Press.

Rogers, S. (2007) "Learning braille and print together - the mainstream issues." British Journal of Visual Impairment, 25(2), 120-132.

Roulston, K. (2010) “"There is no end to learning': Lifelong education and the joyful learner." International Journal of Music Education, 28(4): 341-52.

Rowden, T. (2009) The Songs of Blind Folk: African American Musicians and the Cultures of Blindness. Ann Arbor, MI: University of Michigan Press.

Ruddock, P. and Bishop, J. (2006) Disability Standards for Education 2005. Barton, Canberra: Commonwealth of Australia. 
Ryan, G. and Bernard, H. (2000) "Data management and analysis methods." In N. Denzin and Y. Lincoln (Eds.), Handbook of Qualitative Research, 769-802. Thousand Oaks, CA: Sage.

Ryen, A. (2004) “Ethical issues.” In C. Seale, G. Gobo, J. F. Gubrium and D. Silverman (Eds.), Qualitative Research Practice, 230-47. London: Sage.

Schön, D. (1983) The Reflective Practitioner: How Professionals Think in Action. New York, NY: Basic Books.

Schön, D. (1987) Educating the Reflective Practitioner: Toward a New Design for Teaching and Learning in the Professions. San Francisco, CA: Jossey-Bass.

Seale, C. (1999a) "Quality in qualitative research.” Qualitative Inquiry, 5(4): 465-78.

Seale, C. (1999b) The Quality of Qualitative Research (Introducing Qualitative Methods Series, D. Silverman, Ed.). London: Sage.

Seale, C. (2002) "Quality issues in qualitative inquiry.” Qualitative Social Work, 1(1): 97110.

Shaw, C. (Ed.) (1930) The Jack-Roller. Chicago, IL: University of Chicago Press.

Sikes, P. J. (1985) “The life cycle of the teacher.” In S. J. Ball and I. F. Goodson (Eds.), Teachers' Lives and Careers, 27-60. Lewes, East Sussex, UK: Falmer Press.

Sikes, P. J., Measor, L., and Woods, P. (2001) “Critical phases and incidents.” In J. Soler, A. Craft and H. Burgess (Eds.), Teacher Development: Exploring Our Own Practice (Developing Practice in Primary Education Series), 104-15. London: Paul Chapman Publishing (Sage) for the Open University.

Silverman, D. (2000) Doing Qualitative Research: A Practical Handbook. London: Sage. 
Silverman, D. (2001) Interpreting Qualitative Data: Methods for Analysing Talk, Text and Interaction (2nd ed.). London: Sage.

Silvers, A., Wasserman, D. and Mahowald, M. B. (1998) Disability, Difference, Discrimination: Perspectives on Justice in Bioethics and Public Policy. Lanham, MD: Rowman and Littlefield.

Southall, G. H. (1999) Blind Tom, the Black Pianist-Composer: Continually Enslaved. Lanham, MD: Scarecrow.

Sparkes, A. C. (1994) Understanding Teachers: A Life History Approach (Educational Research Monograph Series, H. A. Radnor, Ed.). Exeter, UK: Research Support Unit, University of Exeter.

Stokes, J. (1993) "Parental perspective: The mainstream education of a child with a severe visual impairment." British Journal of Visual Impairment, 11(3), 97-98.

Tadić, V., Pring, L., and Dale, N. (2010) “Are language and social communication intact in children with congenital visual impairment at school age?" Journal of Child Psychology and Psychiatry, 51(6): 696-705.

Talbot, P. (2002) "The future of special schools for the visually impaired." British Journal of Visual Impairment, 20(2), 56-61.

Talbot, P. and Farbey, L. (1997) "Commentary: The future of the nonmaintained special schools for visually impaired children." British Journal of Visual Impairment, 15(2), 75-77.

Thomas, G. and Jackson, B. (1986) “The whole-school approach to integration.” British Journal of Special Education, 13(1), 27-29. 
Thomas, W. I. and Znaniecki, F. (1919) The Polish Peasant in Europe and America: Monograph of an Immigrant Group (Vol. 3, "Life record of an immigrant"). Boston, MA: Gorham Press (Richard G. Badger).

Titus, P. A. and Gremler, D. D. (2010) “Guiding reflective practice: An auditing framework to assess teaching philosophy and style." Journal of Marketing Education, 32(2): 182-96.

Todd, N. (1992) "The use of portable computers by visually impaired students in mainstream Further Education.” British Journal of Visual Impairment, 10(2), 74-75.

Varvarigou, M. (2014) “ 'Play it by ear': Teachers' responses to ear-playing tasks during oneto-one instrumental lessons." Music Education Research, 16(4): 471-484.

Varvarigou, M. and Green, L. (2014) “Musical 'learning styles' and 'learning strategies' in the instrumental music lesson: The Ear Playing Project (EPP).” Psychology of Music, published first online on 4 June 2014, DOI: 10.1177/0305735614535460

Vitale, J. (2011) "Formal and informal music learning: Attitudes and perspectives of secondary school non-music majors." Teachers International Journal of Humanities and Social Science, 1(5): 1-14.

Webster, A. and Roe, J. (1998) Children with Visual Impairments: Social Interaction, Language and Learning. London: Routledge.

Welch, G. F. (1988) "Observations on the incidence of absolute pitch (AP) ability in the early blind." Psychology of Music, 16(1): 77-80.

Wesseling, L. (in collaboration with J. Clifton and S. Tremaine) (2004) Focus on Braille Music. London: Musicians in Focus.

WHO (World Health Organisation) (2012) Global Data on Visual Impairments 2010. Geneva, Switzerland: WHO Press. 
Wright, R. (2011). Musical Futures: A new approach to music education. Canadian Music Educator, 53(2), 19-21.

Wright, R. (2012). Tuning into the future: Sharing initial insights about the 2012 Musical Futures pilot project in Ontario. Canadian Music Educator, 53(4): 14-18.

Wright, R. and Kanellopoulos, P. (2010) "Informal music learning, improvisation and teacher education." British Journal of Music Education, 27(1): 71-87.

Zimmermann, S.-A. (1997) “Music.” In H. Mason and S. McCall (Eds.), Visual Impairment: Access to Education for Children and Young People, 271-278. Abingdon, Oxfordshire: David Fulton Publishers. 